\title{
Editorial
}

\section{Clinical and Professional Aspects of Opioid Prescribing for Pain Physicians}

\author{
Alan D. Kaye, MD, PhD
}

W

e are all extremely challenged as pain physicians in many ways. At present, our clinical decision making is second guessed by numerous governmental and regulatory agencies, rival pain organizations with different philosophies and politics, and special interest groups, many of whom believe they know much more than we do with regard to the treatment of pain pathogenesis. Furthermore, there are many professionals who present themselves to the public as pain experts or practitioners, even though a significant number of them have had little, if any, pain-related education in medical school or training in residency, and often lack accredited pain fellowships.

This issue of Pain Physician highlights guidelines with regard to opioids (1). The topic of opioid prescribing affects not only every pain physician, but also most every person who suffers from pain and their families. Just last year, the Centers for Disease Control and Prevention provided additional guidelines focused on primary care physicians that require a more critical review of concepts and practice related to opioid medications (2). Given that in a lifetime, the prevalence of having a pain-related process is so high, the decisions we make daily to provide opioids and nonopioid medications have enormous ramifications. My mother, who had 7 back surgeries, had rods placed in her back, and had postherpetic neuralgia, was on opioids for over 2 decades. She had classic and very significant side effects and complications from these agents and other prescribed adjuvants, which provided additive or synergistic effects. Ultimately, 2 years ago she had an overdose which led to a lengthy stay in an intensive care unit. Today, she is not on any opioid medications at all. She occasionally utilizes an acetaminophen tablet, recently started to drive again, reads a book per day, and is better off than at any time that I can recall, even dating back to my childhood.

We, therefore, as subspecialty-trained interventional pain physicians are not immune to any of these painrelated topics and issues. The ever-evolving understanding of benefits and potential harms of these powerful drugs is an ongoing responsibility of each and every pain practitioner. To this end, I was part of a Food and Drug Administration Advisory Board last year that voted unanimously for mandatory continuing medical education for any opioid prescriber in our country. In this regard, data from Medicare Part D Claims indicate that the greatest prescribers of opioids are primary care physicians (family practice and internal medicine) with interventional pain physicians ranked behind nurse practitioners, physician assistants, orthopedic surgeons, physical medicine \& rehabilitation doctors, and anesthesiologists (1). It is with this impetus that many of us have spent recent years working on guidelines, reviews, book chapters, books, projects with Scientific American, teaching classes, and creating courses on substance abuse and all types of best practices in pain management. This current issue of Pain Physician journal builds on many of these topics and should be reviewed closely by all pain physicians worldwide.

Today, I reflect humbly and emotionally on the fact that I personally know or trained multiple pain physicians who are in jail for unethical and illegal behavior; are involved with ongoing and expensive trials that have lasted over extended periods of time; are being reviewed or disciplined by state boards; and unfortunately, some have committed suicide. We feel your pain and on behalf of the many professionals who play pivotal roles in the journal and the From: Department of Anesthesiology and Pain Medicine, Louisiana State University School of Medicine, New Orleans, LA American Society of Interventional Pain Physicians, reach

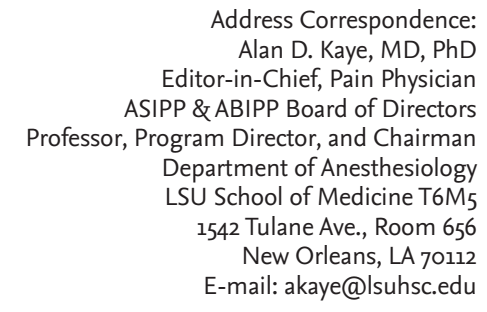

Address Correspondence: Alan D. Kaye, MD, PhD
Editor-in-Chief, Pain Physician \& ABIPP Board of Directors Department of Anesthesiology U School of Medicine T6M New Orleans, LA 70112 E-mail: akaye@lsuhsc.edu 
out to each of you in hope of reconfiguring your clinics and routines, so that you can be successful in all aspects of these practices. If you have questions about anything in this edition of the journal or in your practices, the American Society of Interventional Pain Physicians provides webinars and courses which are extremely helpful in your ongoing education and development. Along the same lines, the American Board of Interventional Pain Physicians provides board certification and competency certification in interventional pain management along with competency certification in controlled substance management and practice management. Some of these aspects are not stressed in medical training or fellowship training.

Certification by American Board of Interventional Pain Physicians is provided by dual pathways with subspecialty certification in pain medicine by the American Board of Medical Specialties' recognized boards with demonstration of additional competency in controlled substance management, practice management, and performance of interventional techniques. The second pathway is through fulfillment of extensive educational requirements (3). We must realize that the world is changing and we must change with it while maintaining the highest ethical and moral standards. For the first time these guidelines provide realistic expectations, considering patient perceptions, shared decisionmaking, and responsible, safe, and effective prescribing of opioids for chronic non-cancer pain. Guidelines also stress evolving concepts in opioid poisonings and deaths related to heroin poisoning, methadone poisoning, and finally, synthetic fentanyl poisonings (1). Please feel free to utilize any of us as a resource if you are unclear about aspects of your practice, whether it be on opioid prescribing, interventional pain techniques, or even legal issues.

"Happiness and challenge in the medical profession is paramount to me and it is miraculous to have the ability to help people in their time of physical, emotional, and/or mental need." This is the first sentence that I wrote on my application to medical school. I still believe it, and being a pain doctor should not be at the cost of your own personal well-being, professional destruction, legal entanglements, or ethical contradictions. Please enjoy and contemplate the many lessons provided through this and every edition of our journal. In particular, know that you are not alone in this world and there are hundreds, if not thousands, of pain physician colleagues here to support and to help you as we all move forward in our lives.

\section{References}

1. Manchikanti I, Kaye AM, Knezevic NN, McAnally H, Trescot AM, Blank S, Pampati V, Abdi S, Grider JS, Kaye AD, Manchikanti KN, Cordner HJ, Gharibo CG, Harned ME, Albers SL, Atluri S, Aydin SM, Bakshi S, Barkin R, Benyamin RM, Boswell MV, Buenaventura RM, Calodney AK, Cedeno DL, Datta S, Deer TR, Fellows B, Galan V, Grami V, Hansen
H, Helm S II, Justiz R, Koyyalagunta D, Malla Y, Navani A, Nouri K, Pasupuleti R, 2 . Sehgal N, Silverman SM, Simopoulos TT, Singh V, Slavin KV, Solanki DR, Staats PS, Vallejo R, Wargo BW, Watanabe A, Hirsch JA. Responsible, safe, and effective prescription of opioids for chronic non-cancer pain: American Society of Interventional Pain Physicians (ASIPP) guidelines.
Pain Physician 2017; 20:S3-S92.

2. Dowell D, Haegerich TM, Chou R. CDC Guideline for prescribing opioids for chronic pain - United States, 2016. JAMA 2016; 315:1624-1645.

3. American Board of Interventional Pain Physicians. www.abipp.org/ 